\title{
Dampak Diversifikasi Ekspor terhadap Pertumbuhan Ekonomi Negara-Negara Anggota ASEAN
}

\author{
Faizal Amir $^{1 *}$, Dedi Budiman Hakim², Tanti Novianti \\ ${ }^{1}$ Universitas Muhammadiyah Malang \\ ${ }^{2}$ Departemen Ilmu Ekonomi \\ Fakultas Ekonomi dan Manajemen, Institut Pertanian Bogor \\ "Korespondensi: faizalbkl63@gmail.com
}

[diterima: September 2018- revisi: November 2018-diterbitkan daring: Desember 2018]

\begin{abstract}
ABSTRAK
Penelitian ini bertujuan untuk menganalisis dampak diversifikasi ekspor terhadap pertumbuhan ekonomi di ASEAN. Data dalam studi ini menggunakan data delapan negara anggota ASEAN pada periode 20062014. Variabel terikatnya yaitu pertumbuhan PDB per kapita, sedangkan variabel bebasnya merujuk pada Teori Pertumbuhan Solow yang menggunakan variabel jumlah tenaga kerja, total investasi dan sebagai indikator diversifikasi ekspor menggunakan variabel indeks. Observasi ini menggunakan Model pooled Least Square (PLS) sebagai model terbaik. Berdasarkan hasil estimasi data dapat diambil kesimpulan bahwa mayoritas negara anggota ASEAN memiliki hubungan positif antara indeks diversifikasi ekspor dan pertumbuhan PDB per kapita. Pada saat krisis, indeks diversifikasi ekspor di ASEAN tidak memiliki dampak positif pada pendapatan nasional, dibuktikan dari koefisien negatif pada variabel dummy interaksi antara krisis global 2008 dan indeks diversifikasi ekspor.
\end{abstract}

Kata kunci: ASEAN, Diversifikasi Ekspor, Pertumbuhan Ekonomi

\begin{abstract}
This study aims to analyze the impact of diversification of exports on economic growth in the ASEAN. The sample used in this study is the eight member countries of ASEAN for the period of 2006-2014. The dependent variable is the growth of income per capita, while the independent variable is based on the theory of Solow growth, namely number of workers, total of investment and export diversification index. The method used is pooled least square. Based on these results, the majority of ASEAN countries have positive relation between export diversification index and the growth of income per capita. At times of crisis, the export diversification index in the ASEAN is no longer have positive impact on national income which is shown by the negative coefficient of the dummy variable interaction between the global crisis of 2008 end export diversification index.
\end{abstract}

Keywords: ASEAN, economic growth, export diversification JEL Classification: C33, F63, 047 


\section{PENDAHULUAN}

Salah satu kestabilan variabel makroekonomi fundamental negara yang harus dijaga adalah kestabilan variabel net-ekspor yang umumnya disebut dengan neraca perdagangan. Bahkan sejak tahun 1995, WTO semakin masif untuk memperlancar arus ekspor dan impor antar negara dengan menurunkan tarif sampai nol persen (Sari et al. 2014). Sejalan dengan penelitian terdahulu, perdagangan internasional sangat berperan dalam menumbuhkan ekonomi setiap negara dan dunia (Zulkarnaen et al. 2012).

Salah satu kawasan integrasi yang memiliki persentase negara berkembang sebesar 90 persen adalah ASEAN. ASEAN juga merupakan wilayah yang memiliki kontribusi perdagangan cukup besar terhadap total perdagangan dunia yaitu sebesar 29 persen (Nouren dan Mahmood 2014). Ketergantungan ekspor yang tinggi negara-negara ASEAN pada negara-negara tujuan dan produk tertentu membuat pertumbuhan ekonominya rentan terhadap guncangan-guncangan eksternal dan hal tersebut akan membuat perekonomian cenderung tidak stabil (Hasanah 2015). Oleh karena itu, ketergantungan yang tinggi pada produk ekspor dan negara tujuan tertentu harus dikurangi agar perolehan nilai ekspor dan pendapatan nasional tetap stabil saat terjadi guncangan eskternal (Hesse 2008). Secara teoritis, peningkatan nilai ekspor akan berdampak pada perubahan output, kemudian peningkatan tersebut dapat menjadi determinan dalam pertumbuhan produksi dan tenaga kerja yang ditunjukkan melalui peningkatan PDB (Olaleye et al. 2013).

Fenomena krisis global yang terjadi memberikan dampak negatif pada menurunnya pendapatan negara yang bersumber dari ekspor. Negara-negara di Eropa dan Amerika serikat yang menjadi tujuan ekspor utama negara-negara anggota ASEAN umumnya menurun daya belinya pada saat krisis melanda. Diversifikasi negara tujuan dan produk ekspor disarankan menjadi solusi saat terjadi krisis untuk dapat meminimalisasi kerugian neraca perdagangan yang dialami. Walaupun tidak dapat dipungkiri bahwa konsentrasi ekspor yang semakin tinggi atau dapat diistilahkan dengan ekspor yang semakin terspesialisasi juga berpengaruh positif terhadap pertumbuhan ekonomi (Aditya dan Acharyya 2013).

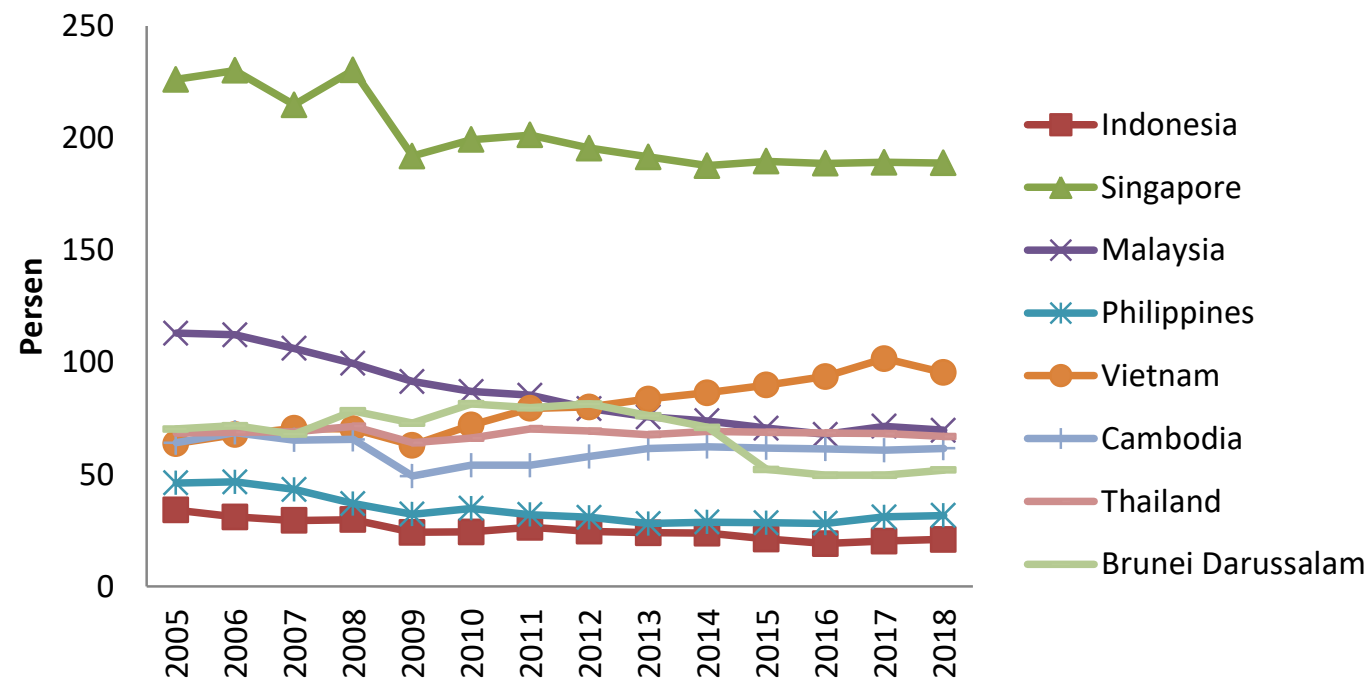

Sumber : World Bank (2019)

Gambar 1. Kontribusi Nilai Ekspor terhadap PDB (persen) Negara Anggota ASEAN Tahun 2005-2018 
Berdasarkan Gambar 1, negara-negara di kawasan ASEAN yang memiliki persentase kontribusi ekspor terhadap PDB di bawah 50 persen hanya dua negara yaitu Indonesia dan Filipina, sedangkan negara dengan persentase kontribusi ekspor terhadap PDB terbesar adalah Singapura. Hal tersebut menunjukkan bahwa stabilnya variabel ekspor memiliki pengaruh yang dominan pada tingkat kestabilan ekonomi negaranegara di kawasan ASEAN. Berbagai guncangan eksternal global yang berpengaruh pada tidak stabilnya nilai tukar akan memperburuk kondisi perekonomian di kawasan ASEAN karena ketergantungan kawasan tersebut pada nilai ekspor cukup tinggi untuk menopang pendapatan nasionalnya. Nilai ekspor akan lebih stabil saat terjadi guncangan eksternal jika konsentrasi ekspor suatu negara terhadap jenis produk dan negara tujuan tertentu dikurangi. Konsentrasi ekspor suatu negara dapat turun dengan menerapkan kebijakan diversifikasi ekspor yang masif dan efektif.

Hasil penelitian ini diharapkan dapat berguna bagi penulis maupun pihak-pihak lain yang berkepentingan. Manfaat yang diharapkan tersebut antara lain:

1. Bagi pemerintah atau institusi terkait diharapkan dapat memberikan masukan dan bahan pertimbangan baik dalam perencanaan maupun dalam pengambilan keputusan terkait dengan perdagangan internasional.

2. Bagi pembaca diharapkan dapat menjadi sumber informasi dan masukan dalam penelitianpenelitian selanjutnya.

Saat ini banyak negara mulai membenahi sistem dalam mekanisme ekspornya dengan melakukan kebijakan diversifikasi sebagai upaya jangka panjang untuk menjaga stabilitas pertumbuhan ekonomi negaranya. Kebijakan setiap negara di wilayah ASEAN yang diberlakukan untuk mencapai keberhasilan diversifikasi ekspor tentunya memiliki persamaan dan perbedaan yang disesuaikan dengan kondisi ekonomi negaranya. Kebijakan diversifikasi ekspor negara yang efektif perlu diadopsi oleh negara lainnya atau dijadikan bahan evaluasi untuk kebijakan yang sudah diterapkan. Penerapan kebijakan diversifikasi ekspor pada umumnya misalnya dengan menambah jenis produk yang berorientasi ekspor, meningkatkan penggunaan teknologi untuk produk ekspor, meningkatkan jumlah produk yang dapat diekspor dan memperluas pasar ekspor. Berdasarkan penjelasan di atas, maka dapat dirumuskan permasalahan sebagai berikut:

1. Bagaimana kebijakan negara-negara anggota ASEAN untuk mencapai keberhasilan diversifikasi ekspor?

2. Bagaimana pengaruh diversifikasi ekspor terhadap pertumbuhan ekonomi negara-negara di kawasan ASEAN?

\section{Tinjauan Teoritis dan Studi Terdahulu Teori Pertumbuhan Solow}

Perdagangan internasional merupakan transaksi jual beli barang dan jasa yang dilakukan oleh penduduk suatu negara dengan penduduk di negara lainnya atas dasar kesepakatan bersama. Penduduk yang dimaksud dapat berupa antarindividu (individu dengan individu), individu dengan pemerintah suatu negara atau pemerintah suatu negara dengan pemerintah negara lainnya. Perdagangan Internasional tercermin dari kegiatan ekspor dan impor dimana hal tersebut menjadi salah satu komponen dalam pembentukaan PDB suatu negara (Produk Domestik Bruto) dari pendekatan pengeluaran. Peningkatan ekspor bersih menjadi faktor penting untuk dapat meningkatkan nilai PDB suatu negara.

Negara-negara yang terlibat dalam perdagangan internasional memiliki dua alasan untuk melakukan perdagangan internasional. Pertama, negara-negara tersebut melakukan perdagangan karena memiliki perbedaan sumberdaya antara negara satu dengan negara lainnya, seperti perbedaan permintaan dan penawaran sumberdaya yang dimiliki atau yang ingin dimiliki. Perbedaan penawaran disebabkan oleh faktor produksi dan teknologi, sedangkan perbedaan permintaan disebabkan oleh jumlah penduduk, selera masyarakat dan pendapatan. Kedua, negara-negara tersebut melakukan perdagangan untuk mencapai skala ekonomi yang lebih tinggi di dalam produksi. Setelah terjadi perdagangan, kekuatan permintaan 
dan penawaran tersebut menentukan harga relatif (pada saat keseimbangan) di masing-masing negara.

\section{Integrasi Ekonomi}

Definisi integrasi ekonomi yang ditandai oleh adanya mobilitas barang dan jasa antarwilayah, serta faktor ini sejalan dengan definisi integrasi menurut United Nation Conference on Trade and Development (UNCTAD). UNCTAD mendefinisikan integrasi ekonomi sebagai kesepakatan yang dilakukan untuk memfasilitasi perdagangan internasional dan pergerakan faktor produksi lintas negara. Menurut Salvatore (1997) teori integrasi ekonomi mengacu pada penghapusan kebijakan hambatan-hambatan tarif maupun non-tarif dalam suatu wilayah pabean tertentu. Maksudnya adalah negara-negara yang tergabung dalam integrasi ekonomi kawasan tertentu akan menghapuskan tarif dalam perdagangan anatarnegara anggota, namun setiap negara akan menerapkan kebijakan hambatan tarif maupun non-tarif tersendiri jika melakukan perdagangan dengan negara non-anggota pabean. Integrasi ekonomi memiliki berbagai tingkatan mulai dari pengaturan perdagangan preferensial, kemudian dikembangkan menjadi pembentukan kawasan bebas, selanjutnya menjadi persekutuan pabean, pasaran bersama dan terkahir akan ada penyatuan ekonomi secara komprehensif.

Pembentukan integrasi ekonomi akan memunculkan dampak-dampak kesejahteraan bagi negara-negara anggotanya. Salah satu diantaranya adalah dengan minimnya biaya administrasi karena berkurangnya jumlah kantor pabean, fungsi patrol perbatasan dan sebagainya. Biaya-biaya besar yang terjadi pada perdagangan internasional akan lenyap atau berkurang setelah terbentuknya integrasi ekonomi. Selain itu, negara-negara yang membentuk persekutuan akan mengalami perbaikan kondisi nilai tukar perdagangannya ketika efek diversi terjadi yaitu dengan peningkatan penawaran produk ekspor yang dimiliki. Kondisi sebaliknya, efek kreasi dapat terjadi jika setelah membentuk integrasi suatu negara mengalami peningkatan impor yang cukup signifikan dan hal ini akan memperburuk nilai tukar perdagangannya.

\section{ASEAN Free Trade Area}

Asosiasi negara-negara di kawasan Asia Tenggara (ASEAN) berkomitmen untuk meliberalisasi perdagangan yang tercermin dengan terwujudnya ASEAN Preferential Trade Arrangement (PTA) yang diperkenalkan pada tahun 1976. Selanjutnya, pada tahun 1992 negaranegara anggota ASEAN membentuk tipe integrasi yang lebih tinggi yaitu ASEAN Free Trade Area (AFTA). AFTA disepakati pada 28 Januari 1992 di Singapura. Awalnya ada enam negara yang menyepakati AFTA, yaitu: Brunei Darussalam, Indonesia, Malaysia, Filipina, Singapura dan Thailand. Vietnam bergabung tahun 1995, sedangkan Laos dan Myanmar pada tahun 1997. Kemudian Kamboja mulai bergabung pada tahun 1999.

ASEAN Free Trade Area (AFTA) merupakan kawasan perdagangan bebas ASEAN dimana tidak berlaku hambatan tarif maupun hambatan non tarif bagi negara-negara anggota ASEAN. Penghapusan tarif menjadi nol persen di kawasan ASEAN dilakukan secara bertahap dari tahun 1992 hingga tahun 2010. Sejak tahun 2010, terdapat sekitar 8000 produk yang termasuk dalam daftar tarif perdagangan produk kawasan ASEAN sebesar nol persen. Kebijakan tersebut diharapkan mampu meningkatkan frekuensi dan efisiensi perdagangan di kawasan ASEAN. Di sisi lain, tujuan utama pembentukan AFTA adalah untuk meningkatkan daya saing ekonomi negara-negara ASEAN dengan menjadikan ASEAN sebagai basis pasar dunia, untuk menarik investasi dan meningkatkan perdagangan antar anggota ASEAN.

\section{Teori Pertumbuhan Solow}

Perbedaan pendapatan nasional antarnegara dapat disebabkan karena adanya perbedaan modal, tenaga kerja dan teknologi yang dimiliki. Model pertumbuhan Solow menjelaskan bagaimana pertumbuhan tenaga kerja, pertumbuhan investasi dan pertumbuhan teknologi berinteraksi dalam perekonomian, serta melihat implikasinya terhadap pendapatan atau output barang dan jasa suatu 
negara secara agregat (Mankiw 2007). Kenaikan ouput perekonomian dalam model pertumbuhan Solow disebabkan karena adanya peningkatan pada jumlah modal dan tenaga kerja. Peningkatan jumlah modal tersebut dapat dilihat melalui peningkatan jumlah tabungan maupun investasi. Sedangkan peningkatan tenaga kerja dapat dilihat dari peningkatan jumlah populasi yang siap masuk dan bersaing dalam pasar tenaga kerja. Oleh karena itu model Solow menyatakan bahwa output bergantung pada persediaan modal dan tenaga kerja yang tersedia:

$Y=f(K, L)$

dimana:

$\mathrm{Y} \quad=$ Output atau pendapatan nasional

$\mathrm{K}=$ Jumlah kapital (persediaan modal)

$\mathrm{L}=$ Jumlah tenaga kerja

\section{Diversifikasi Ekspor}

Teori perdagangan internasional klasik menyatakan bahwa negara sebaiknya fokus untuk melakukan spesialisasi daripada melakukan diversifikasi pada produk ekspornya. Selain itu, Hecksker-Ohlin juga menyatakan bahwa setiap negara seharusnya melakukan spesialisasi untuk dapat melakukan ekspor secara intensif (Markusen et al. 1995). Akan tetapi, diversifikasi ekspor dewasa ini sangat dibutuhkan karena meningkatnya jenis komoditas dengan harga dan volume yang volatil, hal ini dapat mempengaruhi kestabilan perekonomian dalam jangka panjang. Oleh karena itu, setiap negara membutuhkan kebijakan ekspor yang diharapkan mampu menjaga kondisi pertumbuhan ekonomi, khususnya variabel ekspor tetap stabil saat terjadi guncangan eksternal.

Diversifikasi ekspor merupakan kebijakan untuk melakukan perubahan pada komposisi produk primer menjadi manufaktur maupun dengan memperluas negara tujuan ekspor atau dengan menambah sektor ekonomi yang terlibat dalam ekspor suatu negara (Samen 2010). Diversifikasi ekspor merupakan salah satu strategi yang diterapkan banyak negara berkembang untuk merubah produk ekspor tradisional menjadi produk ekspor non-tradisional. Semakin banyaknya jenis produk suatu negara yang dapat diekspor dapat menurunkan ketidakstabilan penerimaan ekspor, meningkatkan pendapatan ekspor, meningkatkan nilai tambah produk dan mencapai pertumbuhan ekonomi yang lebih stabil. Selain itu, adanya kebijakan diversifikasi ekspor dapat meningkatkan kemampuan penggunaan teknologi masyarakat suatu negara dan meningkatkan skala ekonomi melalui proses learning by doing (Aditya dan Acharyya 2013). Jadi, suatu negara yang melakukan diversifikasi ekspor bertujuan utama untuk memperbesar perolehan pendapatan nasional dari neraca perdagangannya, dimana dapat dilakukan dengan peningkatan nilai tambah produk ekspor, pengenalan produk baru pada tujuan ekspor lama atau sebaliknya yaitu dengan melakukan penjualan produk lama terhadap pasar ekspor baru.

\section{Indeks Diversifikasi Ekspor}

Di dalam berbagai literatur, terdapat beberapa variasi untuk mengukur tingkat diversifikasi ekspor suatu negara. Ukuran yang paling banyak digunakan untuk mengukur tingkat diversifikasi ekspor adalah dengan menggunakan concentration ratio (konsentrasi produk maupun negara tujuan). Ukuran lain yang juga sering digunakan meliputi yaitu Commodity-Specific Cumulative Export Experience Function (CSCEEF), the Absolute Deviation of the Country Commodity Shares dan the Commodity Specific Traditionalist Index.

Pada penelitian ini akan menggunakan ukuran concentration ratio karena ukuran ini paling sering digunakan oleh berbagai peneliti di tingkat internasional. Concentration ratio sendiri memiliki beberapa ukuran yang sudah dikembangkan oleh para ekonom meliputi yaitu the Hirschman index, the Ogive index, the entropy index, the Herfindahl index, the Aggregate Specialization Index dan the Hirschman-Herfindahl Index (HHI). Pengukuranpengukuran tersebut hampir sama secara konsep dan pendekatannya. The Hirschman Index adalah pengukuran konsentrasi ekspor yang paling banyak digunakan untuk mengukur konsentrasi komoditas perdagangan. Berikut pendekatan matematis dari salah satu ukuran concentration ratio yaitu Hirschman-Herfindahl Index (HHI): 


$$
\text { HHI }=\frac{\sum_{j=1}^{n i}\left(\frac{x i j}{x i}\right)^{2}-\frac{1}{n i}}{1-\frac{1}{n i}}
$$

dimana xij merupakan nilai ekspor komoditi j dari negara $\mathrm{i}$ atau nilai ekspor dari negara $\mathrm{i}$ ke negara $\mathrm{j}$, ni merupakan jumlah komoditi yang diekspor atau jumlah negara tujuan ekspor, sedangkan xi merupakan nilai ekspor total negara i. Semakin tinggi nilai HHI artinya semakin tinggi konsentrasi ekspor suatu negara pada sedikit jenis produk atau negara tujuan ekspor atau dengan kata lain suatu negara dapat dikatakan sedang menerapkan kebijakan spesialisasi ekspor. Begitu juga sebaliknya, jika nilai HHI semakin kecil maka suatu negara dapat dikatakan sedang menerapkan kebijakan diversifikasi ekspor.

\section{Studi Terdahulu}

Penelitian mengenai perkembangan maupun dampak diversifikasi ekspor terhadap pertumbuhan ekonomi sudah dilakukan di tingkat nasional dan banyak dilakukan pada skala internasional. Pada skala internasional, Hesse (2008) melakukan penelitian untuk menganalisis pengaruh diversifikasi ekspor terhadap pertumbuhan ekonomi. Penelitian tersebut menggunakan model panel dinamis sebagai alat analisisnya dengan jumlah data deret waktu sebanyak 35 tahun, namun data deret waktu tersebut dibagi ke dalam enam struktur data sehingga menghasilkan enam estimasi panel dinamis yang lebih spesifik, sedangkan data penampang lintangnya berjumlah 96 negara. Dari hasil penelitian tersebut, variabel-variabel independen yang berpengaruh positif terhadap pertumbuhan ekonomi meliputi yaitu rata-rata lama menempuh pendidikan formal penduduk, jumlah investasi yang masuk dan keterbukaan perdagangan suatu negara. Sedangkan variabel independen yang berpengaruh negatif meliputi yaitu lag dari pertumbuhan PDB per kapita, pertumbuhan populasi dan konsentrasi ekspor. Berdasarkan hasil penelitian tersebut dapat disimpulkan bahwa diversifikasi ekspor akan menyebabkan turunnya konsentrasi ekspor yang selanjutnya dapat menstabilkan dan meningkatkan pertumbuhan ekonomi.

Berbeda dengan Hesse (2008), Herzer dan Nowak-Lehnmann (2006) menggunakan metode analisis dan proksi variabel yang berbeda melalui penelitiannya dengan topik yang sama yaitu tentang dampak diversifikasi ekspor terhadap pertumbuhan ekonomi, namun fokus observasi penelitian tersebut pada satu negara yaitu Chile. Data yang digunakan adalah data tahunan. Penelitian ini menggunakan fungsi produksi CobbDouglas sebagai landasan teori dalam pembuatan modelnya, sedangkan Hesse (2008) menggunakan model pertumbuhan Solow sebagai landasan teorinya. Model deret waktu yang digunakan dalam penelitian Herzer dan Nowak-Lehnmann (2006) tersebut adalah model VAR dengan variabel meliputi yaitu total produksi, akumulasi kapital, jumlah tenaga kerja, jumlah sektor ekspor dan rasio ekspor manufaktur terhadap total ekspor.

Proksi variabel L pada fungsi produksi CobbDouglas di dalam penelitian Herzer dan NowakLehnmann (2006) menggunakan jumlah tenaga kerja, sedangkan proksi variabel L pada model augmented pertumbuhan Solow di dalam penelitian Hesse (2008) menggunakan jumlah populasi. Temuan yang menarik dalam penelitian Herzer dan Nowak-Lehnmann (2006) ini adalah dengan bertambahnya jumlah sektor ekspor lebih berpengaruh signifikan terhadap pertumbuhan ekonomi Chile daripada dengan meningkatkan rasio ekspor produk manufaktur terhadap total ekspor. Selain itu, adanya error correction model (ECM) dalam penelitian tersebut mampu mengoreksi hubungan jangka pendek menuju keseimbangan jangka panjang antara diversifikasi ekspor dan pertumbuhan ekonomi. Kesimpulan lain yang penting dari penelitian Herzer dan Nowak-Lehnmann (2006) tersebut adalah melakukan diversifikasi ekspor dengan berbasis pada pemanfaatan natural resources memainkan peran penting dalam proses pertumbuhan negara berkembang, utamanya pada pemanfaatan hasil pertanian dan pertambangan.

Selanjutnya, pada penelitian terbaru terkait diversifikasi ekspor oleh Aditya dan Acharyya 
(2013) dari Jadavpur University, India. Landasan teori yang digunakan di dalam penelitian ini adalah teori pertumbuhan Harrod-Domar dan berbeda dengan penelitian yang dilakukan oleh Hesse (2008). Peneliti tersebut menggunakan sampel sejumlah 65 negara dengan periode 40 tahun (1965-2005) yang ditelaah melalui pendekatan model panel dinamis. Variabel-variabel yang digunakan meliputi yaitu produk domestik bruto (PDB) riil, nilai ekspor barang dan jasa, nilai investasi, indeks konsentrasi komoditas dan tingkat teknologi ekspor. Variabel yang menjadi variabel dependen adalah variabel PDB riil, berbeda dengan Hesse (2008) yang menjadikan pertumbuhan PDB per kapita sebagai variabel dependennya.

Dalam penelitian ini disampaikan bahwa diversifikasi dan komposisi ekspor merupakan faktor penentu penting untuk meningkatkan pertumbuhan ekonomi setelah mengetahui dampak variabel lain seperti lag dari pertumbuhan PDB, eskpor, investasi dan infrastruktur. Hubungan antara variabel konsentrasi ekspor dan pendapatan nasional ditemukan memiliki hubungan nonlinear dalam penelitian ini. Hubungan variabel konsentrasi ekspor dan pendapatan nasional tersebut dapat bernilai negatif dan kemudian berubah menajdi positif setelah mencapai titik kritis tertentu, perubahan tersebut terjadi karena faktor lain. Selain itu, dampak kebijakan diversifikasi ekspor akan terlihat lebih besar jika ekspor suatu negara lebih besar dari nilai ekspor rata-rata dunia. Penelitian ini juga melakukan estimasi beberapa kali untuk dapat melihat secara langsung perubahan nilai koefisien setiap variabel pada saat sebelum dan setelah ada kebijakan diversifikasi ekspor. Rekomendasi kebijakan dari hasil penelitian ini adalah suatu negara perlu melakukan diversifikasi ekspor jika memiliki nilai konsentrasi ekspor di bawah nilai kritis atau batas maksimal sesuai dengan pola yang diamati dalam penelitian ini. Kemudian, negara-negara yang memiliki nilai konsentrasi ekspor di atas nilai kritis sebaiknya melakukan spesialisasi agar tercapai proses produksi yang lebih efisien.

Siregar dan Daryanto (2005) melakukan penelitian untuk melihat perkembangan diversifikasi ekspor di Indonesia. Penelitian tersebut mendeskripsikan dinamika jangka pendek ekspor Indonesia di awal abad ke-21. Pemaparan pada hasil penelitian dilakukan dengan menggunakan analisis deskriptif kualitatif dan analisis ekonometrika mengenai perkembangan diversifikasi ekspor di Indonesia. Analisis ekonometrika yang digunakan adalah model regresi linear berganda dengan menjadikan koefisien variasi nilai ekspor 25 komoditas utama Indonesia sebagai variabel dependennya dan juga sebagai pengukur tingkat diversifikasi ekspor di Indonesia. Sedangkan variabel independennya meliputi yaitu indeks resiko perekonomian Indonesia dan nilai foreign direct investment (FDI). Berbeda dengan penelitian-penelitian lainnya terkait diversifikasi ekspor, Siregar dan Daryanto (2005) menambahkan variabel indeks resiko perekonomian sebagai variabel yang berpengaruh terhadap diversifikasi ekspor. Berdasarkan hasil penelitian, dapat disimpulkan bahwa telah terjadi perubahan pola perdagangan Indonesia, khususnya ekspor dengan produksi jenis produk dan tujuan ekspor baru. Implikasi kebijakan yang disampaikan peneliti bahwa Indonesia perlu lebih jauh lagi mengupayakan divesifikasi ekspor. Selain itu, faktor investasi asing di Indonesia tidak semata-mata berpengaruh pada keberhasilan diversifikasi ekspor.

De Pineres dan Ferrantino (1995) meneliti tentang diversifikasi dan struktur dinamis ekspor dalam memacu proses pertumbuhan di Chile. Penelitian ini menggunakan data deret waktu sebanyak 30 tahun dari variabel-variabel yang mengukur tingkat diversifikasi dan perubahan struktur ekspor di Chile. Penelitian ini memiliki kesamaan dengan penelitian yang dilakukan oleh Herzer dan Nowak-Lehnmann (2006) yaitu penelitian menggunakan Chile sebagai objek observasi dan menggunakan model VAR. Perbedaannya dengan yang diteliti Herzer dan Nowak-Lehnmann (2006), De Pineres dan Ferrantino menggunakan export composition dan specialization sebagai proksi dari ukuran tingkat diversifikasi ekspor. Peneliti menduga bahwa diversifikasi ekspor atau perubahan produksi dari 
produk ekspor tradisional menjadi non-tradisional merupakan komponen penting untuk memacu pertumbuhan di Chile. Berdasarkan hasil penelitian, diversifikasi ekspor berpengaruh signifikan pada pertumbuhan ekonomi di Chile sejak pertengahan tahun 1970 karena sebelum periode tersebut pemerintahan di Chile dipimpin oleh pemimpin otoriter yang mengambil kebijakan produksi spesialisasi tinggi.

Perbedaan penelitian ini dengan beberapa penelitian terdahulu di atas terletak pada negaranegara yang menjadi objek penelitian, deret waktu penelitian, dan indeks diversifikasi ekspor yang digunakan. Penelitian ini memfokuskan negaranegara yang diamati hanya pada kawasan integrasi ASEAN. ASEAN dipilih karena memiliki kontribusi ekspor terhadap PDB mayoritas di atas 50 persen, sehingga penelitian tentang pengaruh diversifikasi ekspor untuk dapat menjaga kestabilan ekspor di ASEAN penting untuk dilakukan. Selain itu, deret waktu pada penelitian ini menggunakan data-data terakhir sampai dengan tahun 2014, sehingga hasil analisis dalam penelitian ini dapat menggambarkan kondisi terbaru diversifikasi ekpsor di ASEAN. Kemudian, indeks untuk mengukur tingkat diversifikasi ekspor secara horisontal dalam penelitian ini berbeda dengan penelitian-penelitian sebelumnya, pada penelitian ini menggunakan kombinasi dari Hirschman Index dan Herfindahl Index. Sedangkan pada penelitian-penelitian terdahulu sebagian besar menggunakan Herfindahl Index dan Commodity Concentration Index (CCI).

\section{METODE PENELITIAN Model Panel Data}

Data panel merupakan salah satu jenis data yang dapat digunakan dalam analisis model regresi panel data (Panel Data Regression Models) atau disebut juga dengan pooled data (pooling dari pengamatan times series dan cross-section) yaitu kombinasi dari time series dan cross-section data. Data cross section merupakan data yang dikumpulkan dalam satu waktu terhadap banyak individu, perusahaan, negara dan lain-lain. Data time series adalah data yang dikumpulkan dari waktu ke waktu terhadap suatu individu.
Menggunakan data panel memiliki beberapa keuntungan. Menurut Hsiao dalam Firdaus (2011) beberapa kelebihan menggunakan data panel disebutkan sebagai berikut:

1. Dengan mengkombinasikan data time series dan cross section membuat jumlah observasi menjadi lebih besar sehingga parameter yang diestimasi akan lebih akurat,

2. Memberikan data yang lebih informatif, derajat kebebasan tinggi yang membuat model lebih efisien, lebih bervariasi, serta mengurangi kolinieritas antar variabel,

3. Data panel lebih baik dalam hal untuk studi mengenai dynamics of adjustment, yang memungkinkan estimasi masing-masing karakteristik individu maupun karakteristik antar waktu secara terpisah,

4. Mempunyai kemampuan yang lebih baik dalam mengidentifikasi dan mengukur pengaruh yang secara sederhana tidak dapat dideteksi oleh data cross section ataupun time series saja dan mampu mengontrol heterogenitas individu.

Pada analisis model panel data dikenal tiga metode pendekatan estimasi yang ditawarkan yaitu metode kuadrat terkecil (Pooled Least Square), metode efek tetap (Fixed Effect) dan metode efek acak (Random Effect). Metode Fixed Effect yaitu menambahkan dummy variable untuk mengizinkan adanya perubahan pada intersep. Metode Random Effect adalah variasi dari estimasi Generalized Least Squares (GLS). Hampir semua penelitian terdahulu telah menggunakan metode "Fixed Effect" untuk mengestimasi model pertumbuhan yang diteliti. Ketika mengestimasi sebuah data panel untuk negara-negara berbeda, harus ada yang mentolerir intersep secara terpisah untuk obesrvasi yang berbeda. Hal tersebut yang membuat metode ini menarik. Pada konteks ini, maka harus ditentukan secara ekonometrik metode terbaik apa yang harus digunakan untuk mengestimasi data. Pertama, menentukan mana yang lebih cocok apakah "Fixed atau Random Effects". Salah satu cara yang digunakan untuk menyelesaikan masalah tersebut yaitu dengan menggunakan uji Haussman, dimana hasilnya terdapat dua persamaan (Satu untuk Fixed Effects dan Random Effects untuk 
lainnya), selanjutnya lakukan uji berikutnya seperti Chow Test.

\section{Pengujian Model}

Pada analisis model dengan menggunakan data panel, dikenal tiga macam pendekatan yang terdiri dari Pendekatan Kuadrat Terkecil (Pooled Least Squared), Pendekatan Efek Tetap (Fixed Effect Model), dan Pendekatan Efek Acak (Random Effect). Pemilihan model terbaik yang digunakan untuk pengolahan data panel menggunakan beberapa pengujian. Pengujian yang dilakukan antara lain:

\section{Pemilihan model dalam pengolahan data panel}

\section{a) Chow Test}

Chow Test atau Uji-F digunakan untuk memilih kedua model diantara Pooled Least Squared dan Fixed Effect Model dengan hipotesis :

$\mathrm{H}_{0}:$ PLS

$\mathrm{H}_{1}:$ LSDV

Jika pada LSDV, $p$-value lebih kecil dari taraf nyata yang digunakan, maka sudah cukup bukti untuk melakukan penolakan terhadap H0 sehingga model LSDV akan terpilih, dan sebaliknya.

\section{b) Haussman Test}

Haussman Test digunakan untuk memilih model Fixed Effect Model atau Random Effect Model, dengan hipotesis :

$\mathrm{H}_{0}: \mathrm{REM}$

$\mathrm{H}_{1}$ : LSDV

Jika pada REM, $p$-value lebih kecil dari taraf nyata yang digunakan, maka sudah cukup bukti untuk melakukan penolakan H0, sehingga model LSDV yang akan dipilih, dan sebaliknya.

\section{c) LM Test}

Uji ini dilakukan jika Chow Test cukup bukti untuk menolak H0 dan Haussman Test belum cukup bukti untuk menolak $\mathrm{H} 0$, atau sebaliknya. Sehingga model harus diuji kembali dengan $L M$ Test untuk memilih Random Effect Model atau Pooled Least Square dengan hipotesis :

$\mathrm{H}_{0}$ : PLS

$\mathrm{H}_{1}: \mathrm{REM}$
Jika LM lebih besar dari chi-square table maka sudah cukup bukti untuk melakukan penolakan terhadap H0 sehingga model REM yang dipilih, dan sebaliknya.

\section{Pengujian asumsi klasik}

a) Uji Normalitas

Uji normalitas data diperlukan untuk mengetahui apakah error term mendekati distribusi normal atau tidak. Uji normalitas diaplikasikan dengan melakukan tes Jarque Bera, jika nilai probabilitas lebih besar dari taraf nyata yang digunakan maka error term dalam model sudah menyebar normal.

\section{b) Uji Homoskedastisitas}

Agar dapat mendeteksi adanya heteroskedastisitas, dalam hasil olahan data panel dengan Eviews, menggunakan metode General Least Squared (Cross Section Weight), caranya adalah dengan membandingkan nilai sum squared resid pada weighted statistic dengan sum squared resid pada unweighted statistic. Jika sum squared resid pada weighted statistic lebih kecil daripada sum squared resid pada unweighted statistic maka model sudah homoskedastisitas. Langkah yang dapat dilakukan untuk mengatasi masalah heteroskedastisitas adalah dengan mengestimasi General Least Squared (GLS) menggunakan white heterocedasticity. Selain itu dapat juga dilakukan dengan pembobotan Cross Section SUR.

\section{c) Uji Autokorelasi}

Agar dapat mendeteksi ada tidaknya autokorelasi adalah dengan melihat nilai dari Durbin - Watson (DW) statistiknya. Jika nilai DW lebih dari 1,77 atau kurang dari 2,23 maka dapat dikatakan tidak terdapat pelanggaran asumsi klasik autokorelasi pada model.

\section{d) Uji Multikolinearitas}

Suatu model dapat dikatakan mengandung multikolinearitas apabila nilai $\mathrm{R}^{2}$ tinggi tetapi banyak variabel yang tidak signifikan. Model yang memiliki multikolinearitas akan sulit untuk diinterpretasi, namun model tetap dalam kondisi BLUE (Best Linear Unbiased Estimator). Cara untuk mengatasi masalah multikolinearitas dalam 
model maka dapat menggunakan beberapa cara berikut ini: adanya informasi apriori; penggabungan data cross section dengan time series; mengeluarkan suatu variabel atau lebih dan kesalahan spesifikasi; transformasi variabelvariabel dan penambahan data baru.

\section{Model Empirik}

Model yang digunakan pada penelitian ini diadaptasi dari model yang digunakan oleh Hesse (2008). Variabel yang digunakan untuk menganalisis dampak diversifikasi ekspor terhadap pertumbuhan ekonomi di kawasan ASEAN antara lain: Pertumbuhan PDB per kapita, jumlah tenaga kerja, jumlah investasi menggunakan proksi gross fixed capital formation dan indeks diversifikasi ekspor menggunakan proksi dari HirschmanHerfindahl untuk negara-negara di kawasan ASEAN.

Berdasarkan penjelasan di atas maka dapat dirumuskan persamaan tersebut menjadi sebagai berikut:

$$
\begin{aligned}
G D P P C G_{i t}= & a_{0}+a_{1} T L_{i t}+a_{2} I N V_{i t}+a_{3} H H I_{i t}+a_{4} \\
& C_{-} O 8_{i t}+U_{i t}
\end{aligned}
$$

ket:

$$
\begin{aligned}
& a_{0} \quad=\text { Intersep; } \\
& G_{\text {GPPCG }} \quad=\text { Pertumbuhan PDB per kapita } \\
& T L_{i t} \quad=\text { Jumlah tenaga kerja negara } \mathrm{i} \\
& \text { pada tahun } \mathrm{t} \text { (persen usia kerja); }
\end{aligned}
$$

\section{HASIL DAN PEMBAHASAN Uji Model dan Asumsi Klasik}

Perekonomian negara anggota ASEAN masingmasing memiliki kondisi yang berbeda, hal ini disebabkan karena setiap negara memiliki perbedaan dalam banyak sisi, khususnya dalam bidang ekonomi misalnya pada sumberdaya alam, sistem ekonomi, kebijakan-kebijakan ekonomi yang diterapkan, keanggotaan dalam perjanjian perdagangan internasional, sistem nilai tukar yang digunakan dan sebagainya. Pengambilan keputusan dalam meregulasi dan menjaga stabilitas perekonomian setiap negara di ASEAN memiliki pengaruh yang signifikan terhadap kesejahteraan ekonomi warga negaranya. Indikator kesejahteraan ekonomi salah satunya diukur melalui tingkat PDB per kapita. Gambar 2 menunjukkan kondisi perekonomian delapan negara anggota ASEAN yang dilihat keragaannya berdasarkan nilai PDB per kapita dari tahun 2000 sampai dengan tahun 2014.

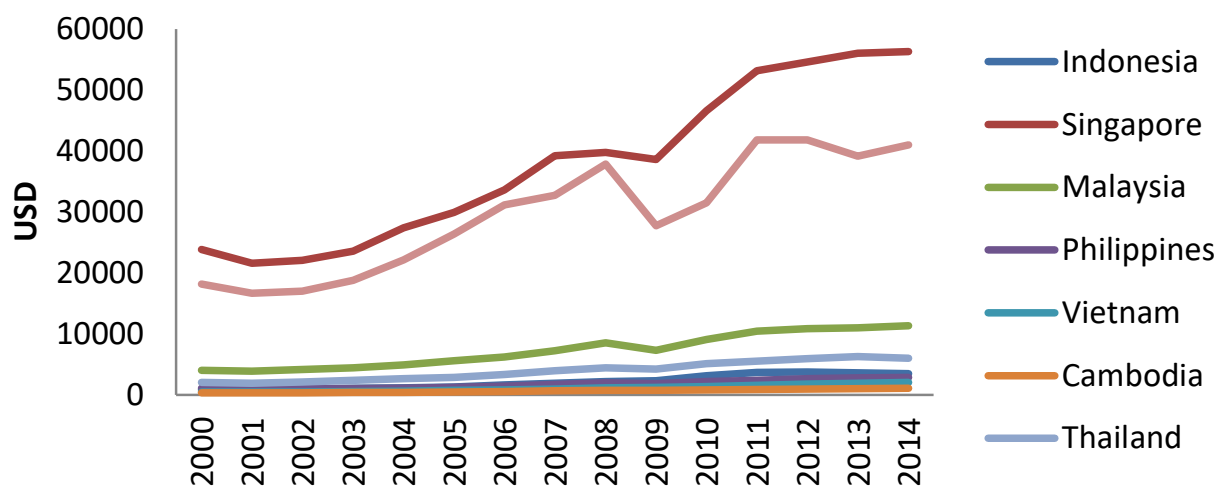

Sumber : World Bank (2016)

Gambar 2. PDB per Kapita (USD) Negara Anggota ASEAN 
Berdasarkan Gambar 2 dapat dijelaskan bahwa Kamboja merupakan negara anggota ASEAN yang memiliki PDB per kapita yang terendah dibandingkan dengan negara anggota ASEAN lainnya. Hal ini dapat disebabkan karena perekonomian yang tidak efisien dan jumlah penduduk Kamboja yang besar tidak ditopang dengan PDB negara yang tinggi. Negara-negara anggota ASEAN mayoritas memiliki PDB per kapita di bawah angka 12000 USD per tahun sampai dengan tahun 2014, berbeda halnya dengan Singapura dan Brunei Darussalam beberapa tahun terakhir sudah mampu mencapai angka PDB per kapita di atas 35000 USD. Sampai saat ini, Singapura merupakan negara anggota ASEAN dengan PDB per kapita tertinggi yaitu berkisar di atas angka 20000 USD per tahun sejak tahun 2000. Pertumbuhan PDB per kapita Singapura yang memiliki tren positif tersebut membuat Singapura memiliki PDB per kapita di atas 50000 USD per tahun sejak tahun 2011. Pertumbuhan PDB per kapita yang tinggi di Singapura terjadi salah satunya karena Singapura merupakan terminal perdagangan internasional terbesar di ASEAN dan terbesar kedua di dunia. Selain itu, Singapura memiliki jumlah populasi penduduk yang rendah yaitu sekitar 5 juta orang dan PDB yang tinggi. Dengan demikian, PDB yang dibagikan kepada penduduk menjadi sangat besar jika dibandingkan dengan negara anggota ASEAN lainnya.

Kondisi ketenagakerjaan di ASEAN menunjukkan bahwa lebih dari 60 persen penduduk usia kerja mampu terserap di pasar tenaga kerja. Berdasarkan Gambar 4, negara dengan penyerapan penduduk usia kerja di pasar tenaga kerja tertinggi yaitu Kamboja, berbanding terbalik dengan kondisi PDB per kapita negara tersebut yang terendah diantara negara-negara di ASEAN. Sedangkan negara dengan penyerapan penduduk usia kerja di pasar tenaga kerja terendah adalah Malaysia yaitu di bawah angka 70 persen berdasarkan data pada Gambar 3.

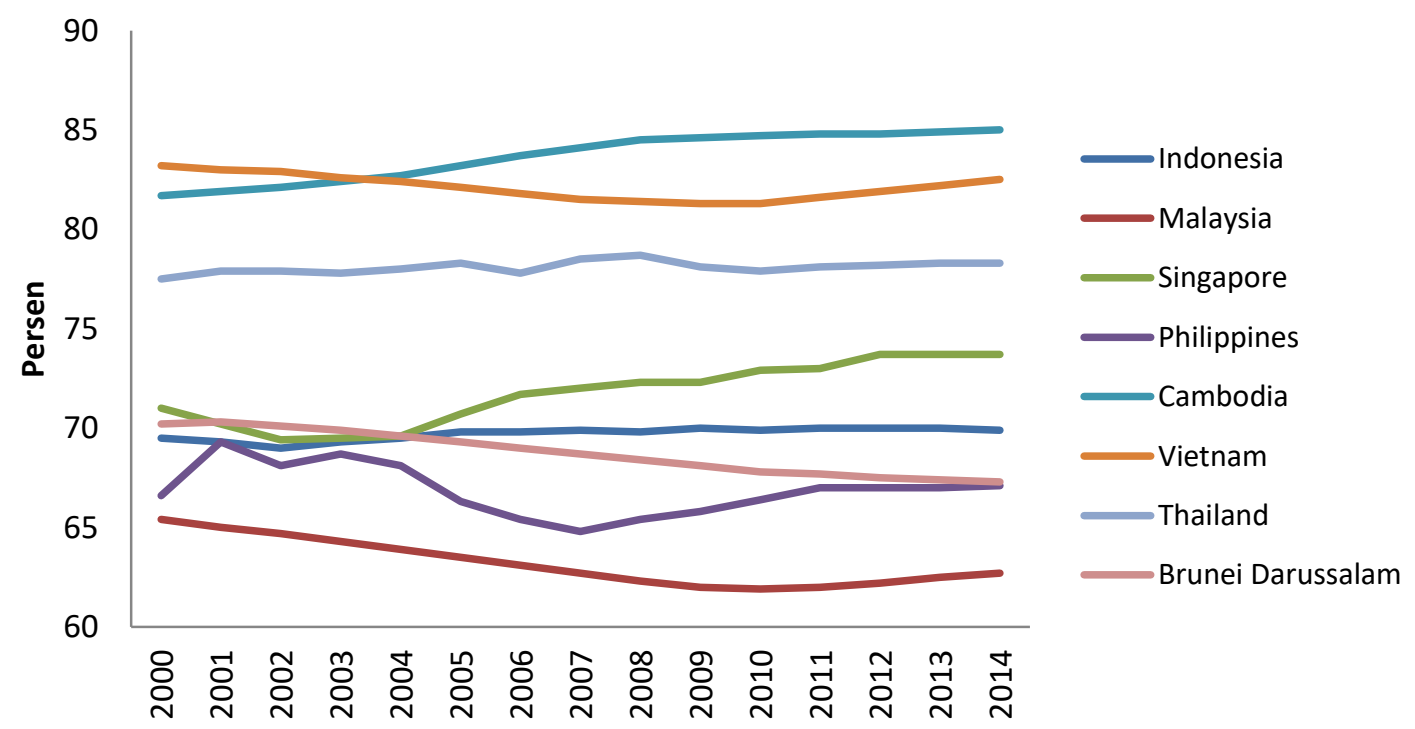

Sumber : World Bank (2016)

Gambar 3. Jumlah Tenaga Kerja (Persen Usia Kerja) Negara Anggota ASEAN

Berdasarkan data pada Gambar 5, negara-negara yang investasinya kurang perkembangan investasi di wilayah ASEAN menunjukkan perkembangan signifikan yaitu menunjukkan tren yang cukup fluktuatif. Kamboja. Perkembangan yang positif dari Indonesia merupakan negara dengan aliran investasi akan berpengaruh pada kontribusi investasi terhadap PDB terbesar di semakin bergeraknya industri sehingga wilayah ASEAN sejak tahun 2010, sedangkan semakin banyak lapangan pekerjaan tersedia. 
Lapangan pekerjaan yang semakin meningkat pengangguran yang ada dalam suatu negara. akan membantu mereduksi kemiskinan dan

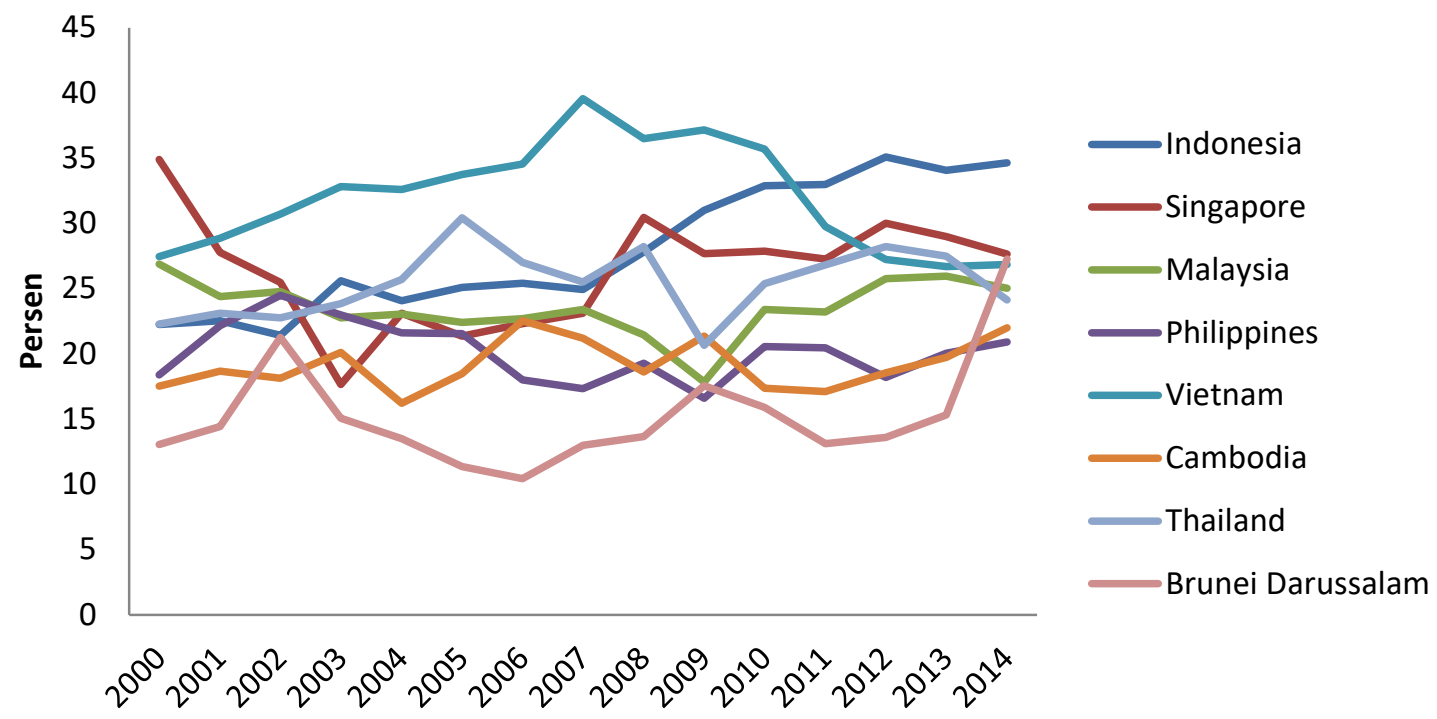

Sumber : World Bank (2016)

Gambar 4. Jumlah Investasi (Persen terhadap PDB) Negara Anggota ASEAN

Berdasarkan Gambar 5, Filipina merupakan adalah Vietnam, namun sejak tahun 2008 negara dengan tingkat penggunaan teknologi pada menunjukkan peningkatan cukup pesat pada produk ekspor tertinggi di ASEAN, namun hal penggunaan teknologi ekspornya. Pada tahun tersebut terus menurun sejak tahun 2003. 2014, Filipina masih menjadi negara dengan Sedangkan negara yang pada awal tahun 2000an sentuhan teknologi pada produk ekspor tertinggi. terendah dalam penggunaan teknologi ekspor

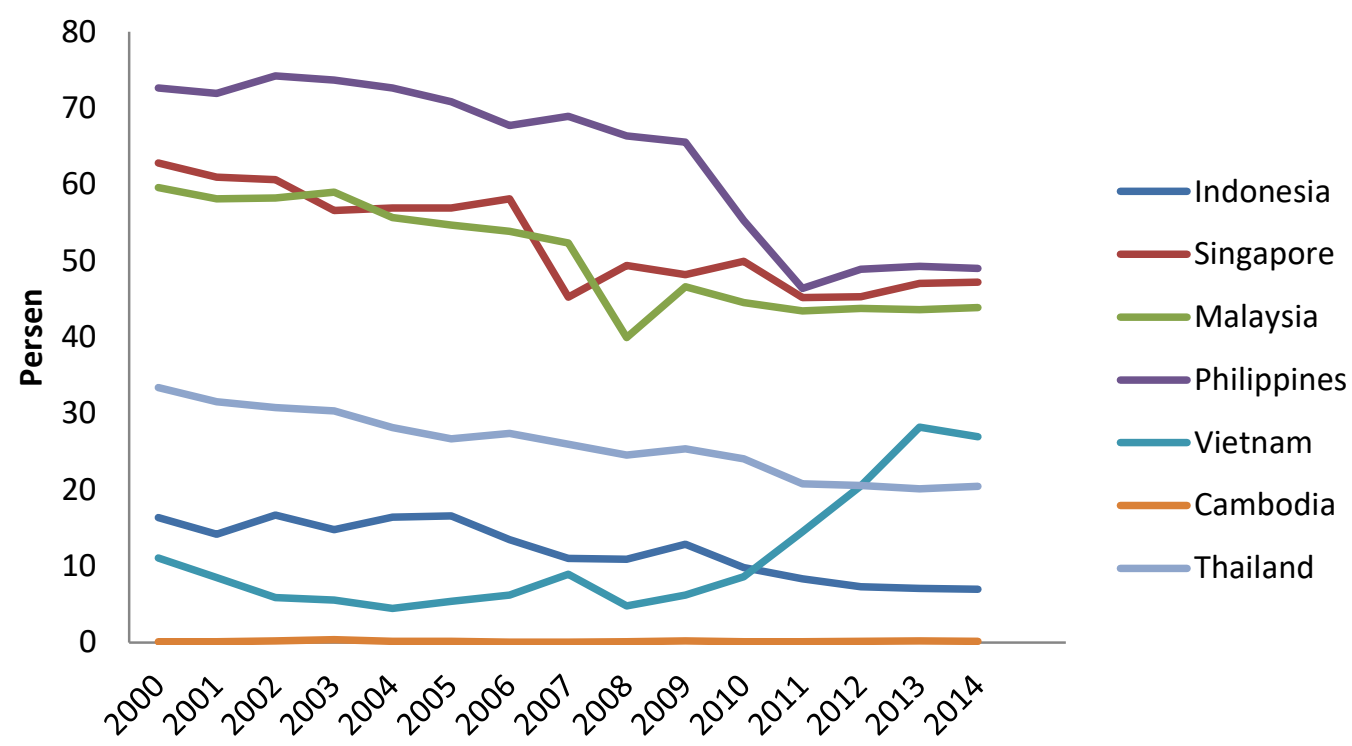

Gambar 5. Tingkat Penggunaan Teknologi pada Produk Ekspor (Persen) Negara Anggota ASEAN 


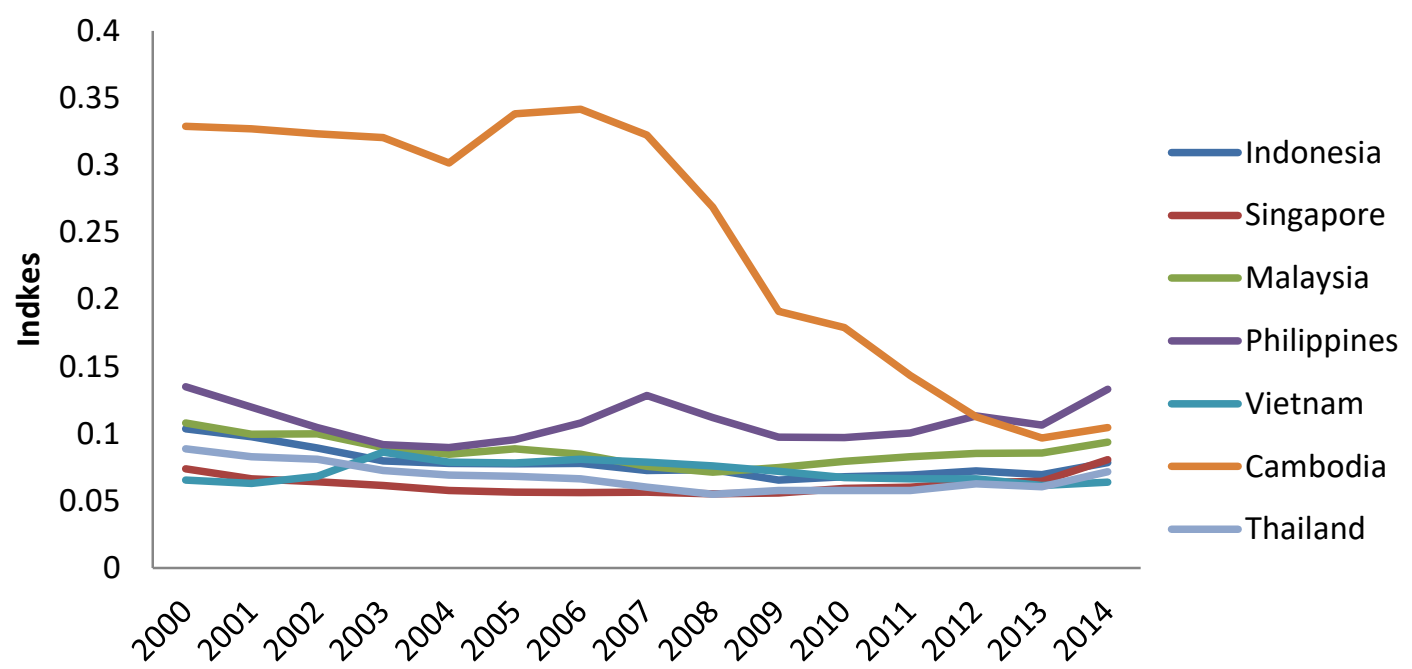

Gambar 6. Indeks Diversifikasi Ekspor Horisontal Negara Anggota ASEAN

\section{Kebijakan Diversifikasi Ekspor Negara Anggota ASEAN}

Kebijakan-kebijakan yang diterapkan untuk meningkatkan dan menstabilkan pendapatan nasional yang bersumber dari ekspor dapat melalui beberapa cara seperti dengan melakukan promosi ekspor, diversifikasi ekspor, pemberian kredit ekspor, standardisasi produk dan kebijakan lainnya. Pada umumnya kebijakan promosi, standardisasi dan pemberian kredit ekspor merupakan kebijakan pendukung untuk terwujudnya diversifikasi ekspor. Negara-negara di Asia Timur dan Asia Tenggara dalam tiga dekade terakhir ini dianggap sebagai wilayah yang cukup berhasil dalam menerapkan kebijakan

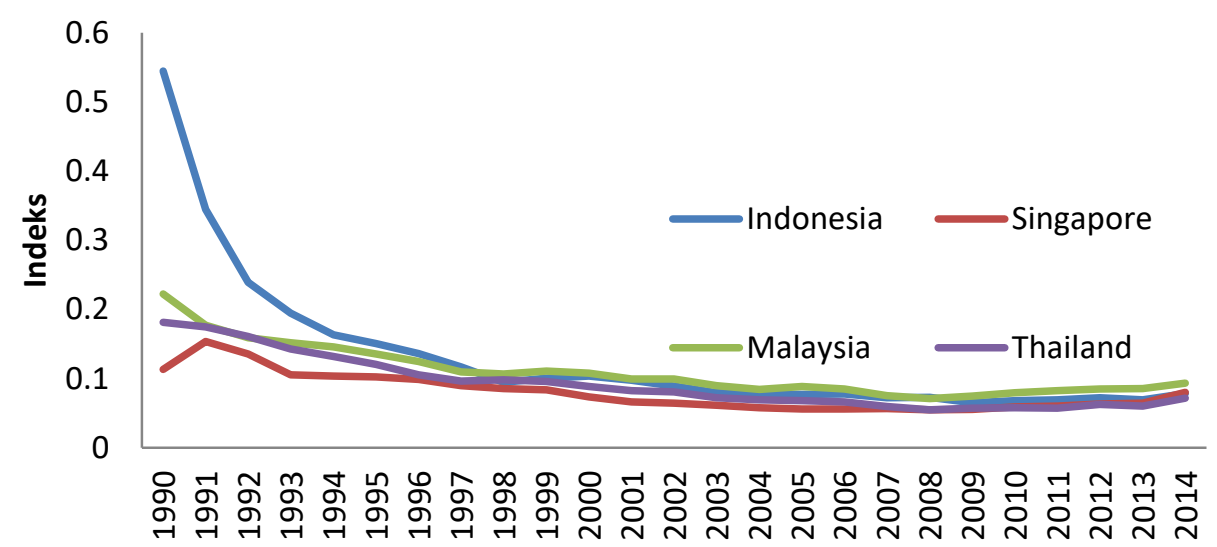

Sumber : World Integrated Trade Solution (2016)

Gambar 7. Indeks Diversifikasi Ekspor Empat Negara Anggota ASEAN 
Pemerintah Indonesia turut serta dalam penerapan kebijakan diversifikasi ekspor, hal yang sama juga dilakukan oleh pemerintah Malaysia dan Thailand untuk mewujudkan keberhasilan diversifikasi ekspor. Pemerintah ketiga negara tersebut cukup aktif dalam menentukan kebijakan pasar di wilayah teritorialnya masing-masing. Arah kebijakan diversfikasi ekspor di Indonesia lebih menitikberatkan pada pemanfaatan sumberdaya lokal yang ditransformasi menjadi produk yang memiliki nilai jual lebih tinggi melalui proses industrialisasi. Diversifikasi yang demikian lebih mengarah pada diversifikasi secara vertikal dengan memanfaatkan teknologi untuk dapat meningkatkan pertumbuhan ekonomi melalui ekspor. Sebagai pendukung target tersebut, pemerintah Indonesia memiliki kebijakan untuk mendukung terwujudnya diversifikasi ekspor berupa national interest account (NIA) yaitu melalui pemberian kredit ekspor yang diemban oleh Lembaga Pembiayaan Ekspor Indonesia (LPEI) atau Indonesian Eximbank (Kementerian Perindustrian 2013). Dana diberikan oleh pemerintah dan masuk dalam perhitungan APBN. Melalui program NIA, pemerintah dapat menetapkan suatu proyek atau transaksi khusus untuk mendorong peningkatan ekspor. LPEI atau Indonesian Eximbank adalah institusi yang dibentuk dengan Undang-Undang Nomor 2 Tahun 2009 untuk mendorong peningkatan ekspor melalui aspek pembiayaan, penjaminan, dan asuransi ekspor.

Selain itu, terkait revitalisasi dan penumbuhan industri hasil hutan dan perkebunan, kebijakan pemerintah saat ini diarahkan kepada dua hal, yaitu peningkatan nilai tambah produk (added value) dan peningkatan daya saing atau kualitas produk. Produk hasil hutan dan perkebunan diusahakan tidak lagi diekspor dalam bentuk bahan baku, namun diolah terlebih dahulu menjadi produk turunannya sehingga nilai tambahnya meningkat. Sedangkan peningkatan daya saing atau kualitas produk dilakukan melalui berbagai upaya oleh pemerintah, antara lain dengan penyusunan dan penerapan SNI, penerapan sertifikasi legalitas untuk produk kayu (SVLK), penggantian mesin- mesin yang telah berumur tua dengan mesin atau teknologi baru supaya proses produksi lebih efisien, serta meningkatkan pasar dengan melaksanakan promosi atau pameran produkproduk hasil hutan dan perkebunan baik di dalam maupun luar negeri.

Pada era pemerintahan tahun 2015, pemerintah menetapkan kebijakan KITE (Kebijakan Impor Tujuan Ekspor) melalui dua mekanisme yaitu fasilitas pembebasan bea masuk dan PPN (Pajak Pertambahan Nilai) impor atas impor bahan baku untuk diolah, dirakit, dipasang yang hasil produksinya diekspor dan fasilitas pengembalian bea masuk atas impor bahan baku untuk diolah, dirakit, dipasang dan hasil produksinya diekspor. Pengertian bea masuk termasuk bea masuk tambahan seperti bea masuk anti dumping, bea masuk pembalasan, bea masuk safeguard, dan bea masuk imbalan.

Selain itu, pemerintah yang baru juga menyediakan fasilitas kredit sebagai stimulus untuk Usaha Mikro, Kecil, dan Menengah (UMKM) dapat meningkatkan daya saing produk ekspor UMKM yang berbasis kerakyatan. Melalui fasilitas kredit ini diharapkan kualitas dan nilai tambah produk ekspor UMKM lebih meningkat. KURBE menyediakan fasilitas pembiayaan ekspor yang lengkap dan terpadu untuk modal kerja (Kredit Modal Kerja Ekspor/KMKE) dan investasi (Kredit Investasi Ekspor/KIE) bagi UMKM. KURBE memiliki tingkat suku bunga 9 persen tanpa subsidi dan penyaluran kredit ini juga akan ditangani Lembaga Pembiayaan Ekspor Indonesia/LPEI (Indonesian Exim Bank). Berjangka paling lama 3 tahun untuk KMKE dan atau 5 tahun untuk KIE, batas maksimal pembiayaan KURBE mikro adalah sebesar Rp 5 miliar. Sedangkan KURBE kecil maksimal kredit yang bisa diberikan sebesar Rp 25 Miliar (dengan ketentuan maksimal KMKE sebesar Rp 15 Miliar) dan KURBE Menengah maksimal sebesar Rp 50 Miliar (dengan ketentuan maksimal KMKE sebesar Rp 25 Miliar).

Selain itu, produk ekspor Indonesia direncanakan akan diperluas negara tujuannya menuju negara-negara di Timur Tengah dan Afrika 
(Kementerian Perindustrian 2016). Neraca perdagangan Indonesia dengan negara-negara di Afrika dan Timur Tengah selama ini masih terbilang kecil, jauh di bawah satu persen dari total produk domestik bruto gabungan antarnegara. Kedua wilayah itu akan diandalkan jika pasar China dan India ikut terimbas krisis. Padahal, di saat ekspor mengalami kejenuhan di Amerika Serikat dan Eropa Barat, Indonesia jelas butuh diversifikasi negara tujuan ekspor ke wilayah Benua Afrika dan Timur Tengah. Kendati di sisi lain, memang harus diakui potensi ekspor Timur Tengah dan Afrika masih cenderung dikesampingkan karena ongkos distribusi ke negara-negara di kedua wilayah tersebut masih cukup mahal. Upaya lain yang dilakukan

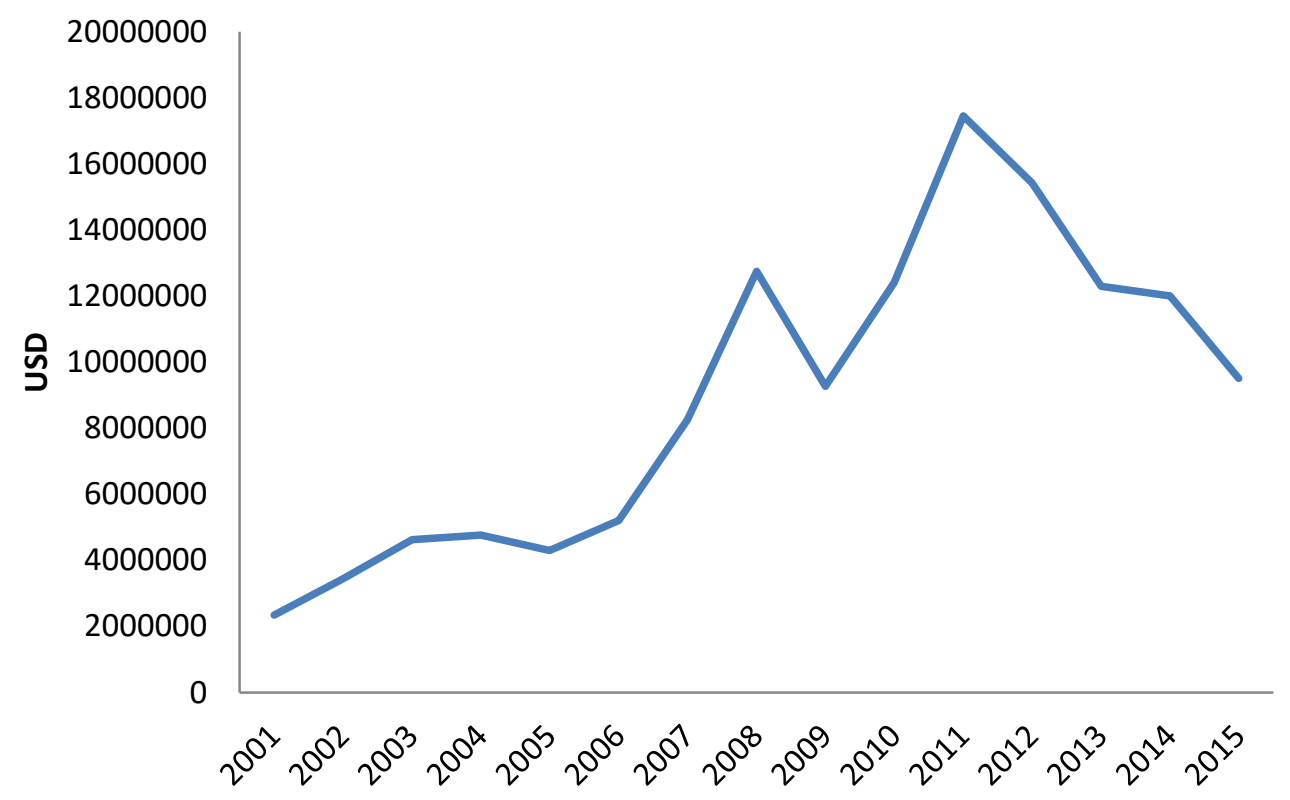

Sumber : International Trade Centre (2016)

Gambar 8. Perkembangan Ekspor Kelapa Sawit dan Turunannya (USD) Malaysia

Malaysia oleh banyak ekonom dianggap sebagai negara kaya sumberdaya alam yang cukup berbeda dengan negara kaya sumberdaya alam lainnya karena dianggap telah berhasil melakukan diversifikasi ekspornya. Hal ini memberikan isyarat bahwa banyak negara yang kaya sumberdaya alam gagal dalam menerapkan kebijakan diversifikasi ekspor. Sejak tahun 1970an, Malaysia sudah berupaya meninggalkan fokus pada karet dan timah sebagai dua komoditi ekspor utama. Saat ini ekspor Malaysia mulai pemerintah Indonesia untuk memperkuat pasar domestik saat terjadi tekanan penurunan ekspor yaitu dengan terus memperkuat pengamanan perdagangan melalui pengontrolan impor.

\section{Malaysia}

Pemerintah Malaysia juga melakukan intervensi pada pelaksanaan kebijakan diversifikasi ekspor di negaranya. Strategi yang diadopsi Malaysia adalah dengan memanfaatkan sumberdaya lokal untuk mengoptimalkan proses produksi ouput berskala ekspor. Beberapa tahun terakhir Malaysia sedang mengembangkan lebih lanjut industri pengolahan turunan minyak kelapa sawit. 
menetapkan kebijakan Export-Oriented FDI yaitu dengan memberikan tax free holidays bagi investor asing yang menanamkan modalnya untuk pembangunan industri berskala ekspor di Malaysia (Yusof 2011). Upaya lanjutan pemerintah untuk mengembangkan industrialiasi berskala ekspor di Malaysia dibuktikan dengan dibuatnya lembaga negara yaitu Malaysia Industrial Development Authority (MIDA). MIDA bekerjasama dengan lembaga pemerintah lainnya yaitu Penang Development Corp (PDC) untuk dapat memenuhi permintaan dan standardisasi yang diminta oleh investor asing.

Pemerintah Malaysia juga menggunakan kebijakan tarif dan restriksi impor untuk dapat melindungi produk dalam negerinya. Kebijakan tersebut membantu untuk promosi ekspor dan melindungi keberlanjutan usaha industri manufaktur domestik. Pada industri lainnya, pemerintah Malaysia juga menetapkan kebijakan standar untuk karet yaitu Standard Manufactured Rubber I (SMRI) agar produk mentah karet diolah terlebih dahulu menjadi produk yang lebih berkualitas sebelum diekspor. Produk turunan karet yang diekspor Malaysia seperti ban dan sarung tangan sebagai wujud diversifikasi ekspor vertikal di Malaysia.

Selain itu, pemerintah Malaysia juga menetapkan kebijakan Standard Malaysian Glove (SMG) agar produk olahan karet Malaysia berupa sarung tangan dapat memiliki kualitas yang sama dan bermutu tinggi sesuai dengan yang ditargetkan pemerintah. Pada tahun 1980an, pemerintah Malaysia juga memproduksi Perusahaan Otomobil Nasional Berhad (Proton) yang berorientasi ekspor dan hasilnya berhasil mengekspor mobil ke sekitar 30 negara di dunia. Setelah berbagai kebijakan diversifikasi ekspor diterapkan di Malaysia, ekspor Malaysia bertransformasi secara drastis, kontribusi ekspor karet dan timah pada total ekspor Malaysia mengalami penurunan yang signifikan yaitu sebesar 60 persen pada tahun 1962 menjadi kurang dari 3 persen pada tahun 2008. Sebaliknya, pada periode yang sama, produk elektronik dan komponen telekomunikasi Malaysia meningkat dari yang sebelumnya kurang dari satu persen menjadi sekitar 50 persen dan sekaligus menjadi kontributor terbesar pada ekspor Malaysia (Sattar 2015).

Selain kebijakan, langkah-langkah strategi yang diterapkan oleh Malaysia sebagai upaya mewujudkan keberhasilan diversifikasi ekspor meliputi yaitu (i) Investasi publik yang signifikan pada bidang pendidikan untuk menciptakan tenaga kerja dengan skill yang handal; (ii) Pendekatan kerjasama antara pemerintah dengan swasta untuk menentukan arah kebijakan, pengembangan pasar dan evaluasi kebijakan ekspor; (iii) Terbukanya peluang asing untuk berinvestasi dalam rangka mengembangkan industri utama seperti pada sektor otomotif dan telekomunikasi, serta hal ini sebagai upaya pengembangan iklim bisnis yang kondusif; (iv) Pengembangan infrastruktur yang signifikan untuk mendukung kemajuan industri seperti jalan, pelabuhan gratis, telekomunikasi dan lainnya; (v) Melakukan privatisasi BUMN agar dapat menciptakan ruang investasi yang lebih luas bagi investor domestik; (vi) Aktif dalam penetapan kebijakan perdagangan regional (ASEAN) dan multirateral (WTO). Pemerintah Malaysia juga membuat Multimedia Super Corridor sebagai upaya untuk menjadikan Malaysia sebagai leader dalam penguasaan aplikasi serta pengembangan teknologi informasi dan komunikasi global, hal tersebut terinspirasi dari pendapat ekonom bahwa teknologi informasi dan komunikasi berkorelasi positif terhadap pelayanan ekspor sehingga dapat menjadi sumber pertumbuhan ekonomi yang lebih baik.

\section{Thailand}

Begitu juga seperti yang dilakukan oleh pemerintah Indonesia dan Malaysia, pemerintah Thailand turut serta mengintervensi kebijakan diversifikasi ekspor di wilayahnya. Strategi utama yang diterapkan untuk mewujudkan diversifikasi ekspor di Thailand yaitu melalui pemanfaatan sumberdaya lokal yang ditransformasi menjadi produk bernilai jual tinggi. Aplikasinya di lapangaan tercermin dari adanya Thailand's agroprocessing. Thailand merupakan contoh negara yang dianggap berhasil menerapkan kebijakan diversifikasi ekspor di dunia (Bonaglia dan 
Fukasaku 2003). Kebijakan-kebijakan yang mendukung keberhasilan tersebut seperti yang dilakukan pemerintah Thailand melalui The Bank of Thailand yaitu dengan memberikan bantuan kredit ekspor kepada para eksportir sejak tahun 1980an agar eksportir sejak saat itu diharapkan dapat meningkatkan nilai tambah produknya. Selain itu, melalui lembaga negara The Department of Export Promotion (DEP), Thailand membentuk kantor pusat perdagangan di luar negeri dan menyediakan informasi terkait perdagangan internasional kepada eksportir. Pemerintah Thailand sesuai dengan yang tercantum pada National Economic and Social Development Plan (NEDP) disepakati untuk memberikan eksportir kemudahan akses terhadap insentif yang dapat diperoleh melalui BOI (The Board of Investment). Pemerintah juga memberikan tax-based incentive untuk perusahaanperusahaan berskala ekspor.

Keberhasilan diversifikasi ekspor di Thailand terwujud dengan menerapkan dual strategy yaitu meningkatkan nilai tambah industri sumberdaya alam yang berorientasi ekspor (seperti hasil pertanian dan perikanan) dan memanfaatkan tenaga kerja secara optimum pada industri-industri yang juga berorientasi ekspor, khususnya pada industri tekstil dan elektronik. Pengembangan produk tradisional yang potensial untuk diekspor dapat menstimulus pertumbuhan agroindustri di Thailand. Selain itu, Thailand juga menerbitkan lisensi dan standardisasi pergudangan untuk menstimulus berkembangnya industri berskala ekspor dan untuk merangsang investasi asing mengalir deras. Foreign Direct Investment (FDI) di Thailand mayoritas bersumber dari negara-negara tetangga di Benua Asia seperti Jepang dan negaranegara Asia NIEs lainnya.

\section{Kamboja}

Perekonomian Kamboja menunjukkan perubahan yang cukup signifikan dalam waktu 15 tahun terakhir, hal ini dibuktikan dengan angka pertumbuhan ekonomi rata-rata yang mencapai sekitar 10 persen setiap tahunnya, tepatnya sejak tahun 1998 sampai tahun 2007.

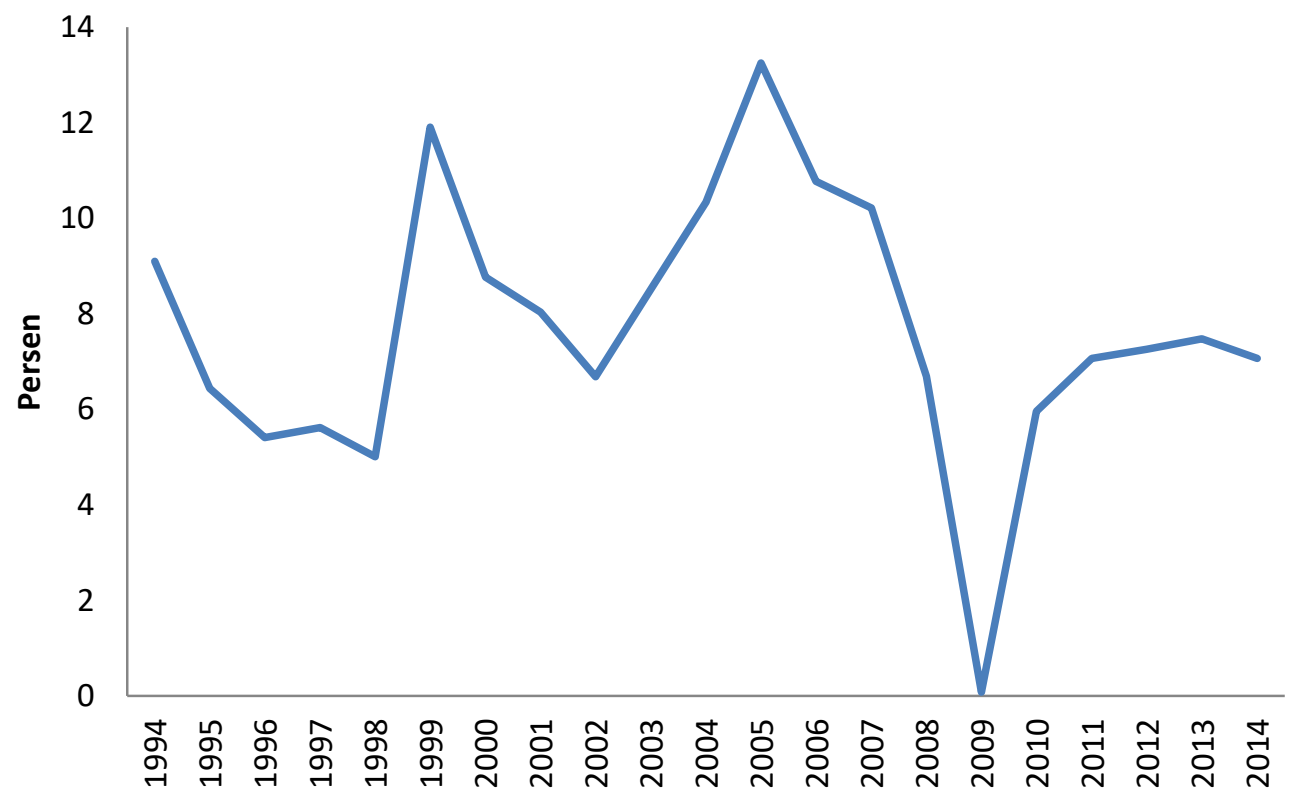

Sumber : World Bank (2016)

Gambar 9. Pertumbuhan PDB Kamboja

Ekspansi ekonomi di Kamboja didorong oleh peningkatan ekspor yang dominan. Kontribusi ekspor Kamboja menunjukkan peningkatan yang signifikan pada PDB yaitu sebesar 16 persen pada tahun 1993 menjadi 60 persen pada tahun 2009. 


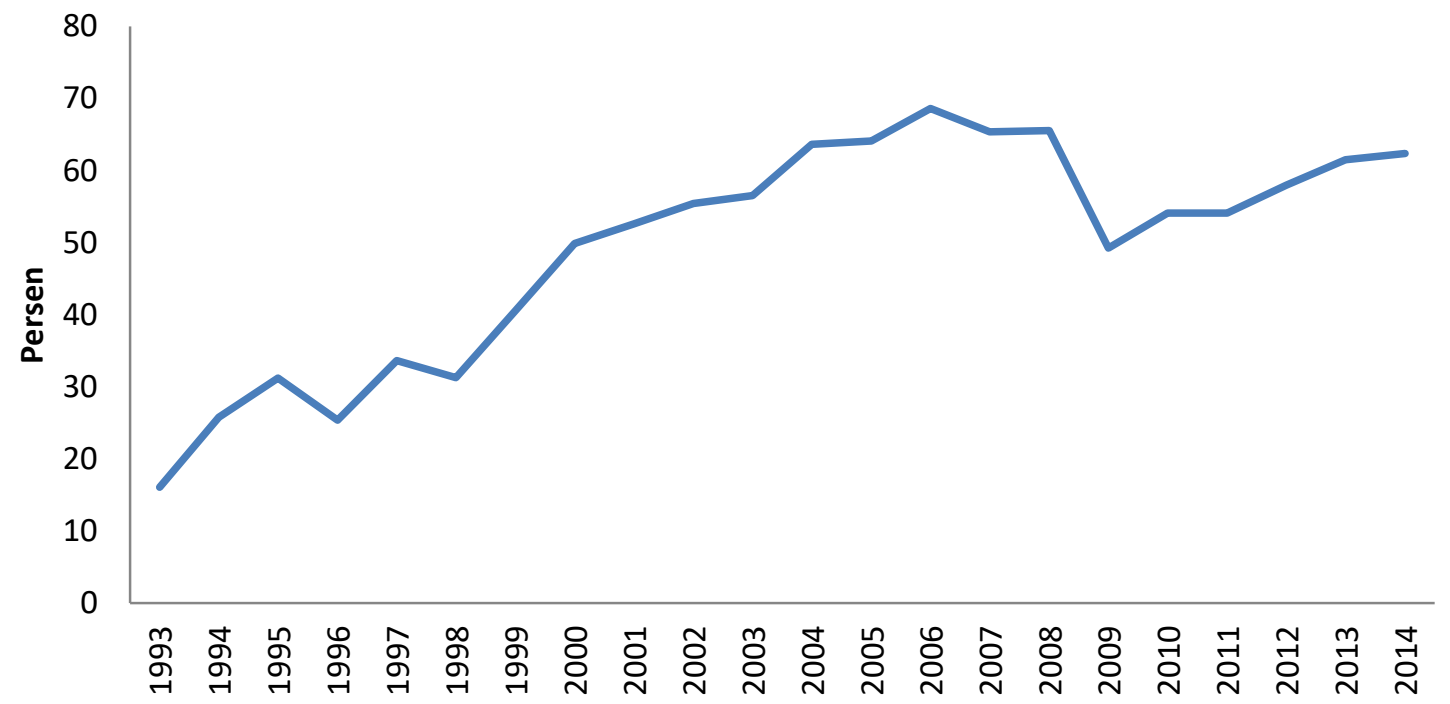

Sumber : World Bank (2016)

Gambar 10. Kontribusi Ekspor Barang dan Jasa terhadap PDB Kamboja

Perkembangan industri tekstil dan garmen merupakan katalisator utama peningkatan ekspor dan PDB di Kamboja. Kontribusinya yang terhitung sebesar 16 persen terhadap PDB pada tahun 2007 telah mampu menyediakan lapangan pekerjaan yang besar di Kamboja. Peningkatan kontribusi ekspor terhadap PDB Kamboja memerlukan kebijakan ekspor yang tepat agar dapat menjaga stabilitas nilai ekspor saat menghadapi guncangan eksternal seperti krisis.

Sebagai upaya untuk mengurangi dampak negatif dari guncangan eksternal dan untuk menambah lapangan kerja, pemerintah Kamboja melakukan berbagai agenda internasional seperti menjadi penggagas utama dalam The Integrated Framework (IF) for Trade-Related Technical Assistance to LDCs. Pemerintah Kamboja mulai menerapkan berbagai strategi diversifikasi ekspor seperti: (i) Mengidentifikasi jenis produk dan jasa yang diprioritaskan untuk meningkatkan penerimaan dan mendiversifikasi ekspor Kamboja; (ii) Menghubungkan lebih jelas pengembangan sektor perdagangan dengan pengembangan sumberdaya manusia dalam upaya mereduksi kemiskinan; (iii) Mengidentifikasi hambatan, baik hambatan ekspor secara umum maupun hambatan spesifik setiap sektor, selanjutnya hambatan tersebut perlu dihapus atau diminimalisai untuk mengembangkan ekspor lebih lanjut; (iv) Proses pelayanan diversifikasi ekspor di Kamboja menjadi tanggung jawab bersama antara pemerintah, swasta dan pemangku kepentingan lainnya, serta dilaksanakan dalam kerangka SWAp perdagangan.

Pemerintah Kamboja membuat program yang disebut CEDEP (Cambodia Export Diversification and Expansion Program). CEDEP dirancang untuk meningkatkan volume ekspor dan diversifikasi produk ekspor di sembilan produk pada Pilar 2 Trade Sector Wide Approach progress (SWAp) Kamboja, dimana sektor ini telah diidentifikasi oleh pemerintah sebagai sektor yang membutuhkan tindakan prioritas (MoC 2014). Sembilan produk tersebut yaitu beras, sutra, singkong, jagung, ikan, pariwisata, garmen, makanan olahan dan perakitan manufaktur. Klasifikasinya meliputi CEDEP I (Beras giling dan sutra bernilai tinggi) dan CEDEP II (Singkong dan produk ikan laut). Tujuan utama komponen ini adalah untuk memperkuat diversifikasi ekspor beras giling dan dirancang untuk mempromosikan ekspor sutra bernilai tambah tinggi, serta meningkatkan daya saing produk sutra Kamboja dalam mendukung diversifikasi ekspor dan pengurangan kemiskinan (melalui pembukaan lapangan kerja, terutama untuk perempuan). Hal ini akan dicapai melalui pelatihan menjahit dan pembinaan dalam pemasaran, desain produk dan peningkatan kualitas, partisipasi dalam pameran perdagangan, 
studi banding ke luar negeri, pengembangan rencana ekspor perusahaan, serta adanya dukungan dan penasehat sutra sektor swasta.

Langkah-langkah lain yang dilakukan oleh pemerintah Kamboja untuk mewujudkan keberhasilan diversifikasi ekspor adalah dengan meningkatkan daya saing produk. Strategi untuk meningkatkan daya saing produk tersebut melalui kebijakan fasilitasi perdagangan, fasilitasi investasi, sanitasi dan perlindungan kekayaan intelektual. Di sisi lain, kebijakan diversifikasi ekspor Kamboja secara horisontal yaitu dengan memperluas tujuan ekspor Kamboja ke wilayah Asia, Timur Tengah dan Afrika.

\section{Vietnam}

Kebijakan diversifikasi ekspor melalui SosioEconomic Development Plan (SEDP) di Vietnam dilaksanakan oleh Kementerian Industri dan Perdagangan Vietnam (MOIT). MOIT telah membuat master plan kebijakan perdagangan, dimana kebijakan ini akan membantu melancarkan hubungan dagang Vietnam dengan negara-negara di dunia. Beberapa tujuan dibuatnya master plan tersebut adalah untuk percepatan ekspor ke berbagai negara tujuan agar keberlanjutan industri dalam negeri juga terjaga, mendorong negosiasi dengan negara-negara mitra dagang seperti di Uni Eropa dan mengembangakan kegiatan yang mendukung peningkatan ekspor seperti melalui promosi ekspor. Pada jangka pendek, SEDP tahun 2010-2015 melaksanakan restrukturisasi ekspor dengan cara mempromosikan produk-produk berorientasi ekspor baru yang memiliki nilai tambah tinggi, mengurangi kontribusi ekspor bahan mentah seperti CPO dan batubara, meningkatkan ekspor produk olahan pertanian, kehutanan, perikanan, mempromosikan ekspor IT, elektronik dan produk software komputer dan menyesuaikan seluruh produk ekspor sesuai dengan standar internasional. Penyesuaian standar ini dilakukan agar produk-produk berorientasi ekspor Vietnam dapat diminati dan diterima di pasar internasional (OECD 2014). Diversifikasi produk tersebut disertai dengan diversifikasi mitra dagang, pertama dari Uni Soviet ke Asia, kemudian ke Eropa dan Amerika Serikat.

\section{Uji Model dan Asumsi Klasik}

Berdasarkan pemilihan model yang dilakukan, model estimasi terbaik untuk mengetahui pengaruh diversifikasi ekspor terhadap pertumbuhan ekonomi negara-negara anggota ASEAN adalah dengan menggunakan pendekatan kuadrat terkecil (Pooled Least Square). Pendekatan ini terpilih setelah melakukan uji Haussman dan uji Chow.

Setelah terpilihnya model PLS sebagai model terbaik maka selanjutnya dilakukan uji asumsi klasik untuk mendapatkan model persamaan yang terbebas dari pelanggaran asumsi dalam analisis regresi seperti uji normalitas, heteroskedastisitas dan autokorelasi. Selanjutnya, untuk mengatasi pelanggaran asumsi heteroskedastisitas yaitu dengan menggunakan estimasi cross section SUR. Model juga sudah tidak melanggar asumsi autokorelasi karena nilai statistik Durbin-Watson sebesar 1.92 berada pada daerah non-autokorelasi. Pengujian terakhir yaitu uji normalitas, probabilitas Jarque Bera sebesar 0.37 lebih besar dari taraf nyata 5 persen ( $>0.05$ ), maka dapat dikatakan bahwa residual dalam model ini menyebar normal.

\section{Hasil Regresi}

Setelah dilakukan uji Haussman dan uji Chow, serta diperoleh model yang paling sesuai, maka selanjutnya dilakukan estimasi dari model panel data yang akan dianalisis. Estimasi persamaan pengaruh diversifikasi Ekspor terhadap pertumbuhan ekonomi negara-negara anggota ASEAN pada Tabel 1 menunjukkan bahwa sebagian besar variabel bebas yaitu jumlah tenaga kerja, jumlah investasi dan indeks diversifikasi ekspor berpengaruh signifikan positif secara statistik. Sedangkan dummy interaksi antara krisis global tahun 2008 dengan indeks diversifikasi ekspor tersebut tidak berpengaruh signifikan secara statistik.

Pada Tabel 1, variabel jumlah tenaga kerja (TL) memiliki hubungan yang positif dengan nilai koefisien 0.222315 , hal ini sesuai dengan hipotesis awal penelitian. Variabel jumlah tenaga kerja berpengaruh nyata pada pertumbuhan PDB per kapita negara anggota ASEAN karena memiliki probabilitas sebesar 0.0000 yang lebih kecil dari 
taraf nyata satu persen. Hubungan yang positif dengan nilai koefisien tersebut menunjukkan bahwa peningkatan jumlah tenaga kerja sebesar satu persen menyebabkan peningkatan pertumbuhan PDB per kapita negara anggota
ASEAN sebesar 0.222315 persen. Hal ini karena saat jumlah tenaga kerja meningkat menunjukkan bahwa faktor produksi suatu negara juga mengalami peningkatan, sehingga akan mampu memperbaiki kondisi perekonomian.

Tabel 1. Hasil Estimasi Dampak Diversifikasi Ekspor terhadap Pertumbuhan Ekonomi Negara-Negara Anggota ASEAN

\begin{tabular}{cccl}
\hline \multirow{2}{*}{ Variabel bebas } & \multicolumn{3}{c}{ Variabel tidak bebas } \\
\cline { 2 - 4 } & Koefisien & Nilai Statistik t & Probabilitas \\
\hline TL & 0.222315 & 7.884626 & $0.0000^{* * * *}$ \\
INV & 1.446263 & 3.621311 & $0.0006^{* * *}$ \\
HHI & 18.90462 & 1.892127 & $0.0628^{*}$ \\
C_08 & -9.20893 & 0.606838 & 0.5460 \\
C & -46.4567 & 3.883348 & $0.0002^{* * *}$ \\
\hline
\end{tabular}

Keterangan: $* * *$ signifikan pada $\alpha=1$ persen, $*$ signifikan pada $\alpha=10$ persen

Selain itu, variabel jumlah investasi (INV) memiliki hubungan yang positif dan memiliki nilai koefisien sebesar 1.446263. Hal tersebut sudah sesuai dengan hipotesis awal dan teori. Hubungan yang positif dengan nilai koefisien tersebut menunjukkan bahwa peningkatan jumlah investasi sebesar satu persen menyebabkan peningkatan pertumbuhan PDB per kapita negara anggota ASEAN sebesar 1.446263 persen. Variabel jumlah investasi siginifikan dengan probabilitas sebesar 0.0006 yang berarti lebih kecil dari taraf nyata satu persen, maka jumlah investasi berpengaruh nyata terhadap pertumbuhan ekonomi negara anggota ASEAN.

Sesuai dengan penelitian Hesse (2008), variabel indeks diversifikasi ekspor (HHI) dengan proksi dari Hirschman-Herfindahl merupakan cerminan seberapa besar konsentrasi ekspor suatu negara. Jika semakin kecil nilai HHI suatu negara, maka semakin meningkat tingkat diversifikasi ekspornya. Sedangkan, Jika semakin besar nilai HHI, maka semakin meningkat tingkat spesialisasi ekspornya. Variabel indeks diversifikasi ekspor berpengaruh positif dan memiliki nilai koefisien 18.90462, hal ini sesuai dengan hipotesis awal dimana jika terjadi peningkatan satu persen indeks diversifikasi ekspor maka akan meningkatkan pertumbuhan PDB per kapita sebesar 18.90462 persen. Variabel HHI signifikan karena memiliki probabilitas lebih kecil dari taraf nyata 10 persen, maka indeks diversifikasi ekspor berpengaruh nyata terhadap pertumbuhan ekonomi di kawasan ASEAN. Hal ini mengindikasikan bahwa kebijakan spesialisasi ekspor yang diterapkan di ASEAN telah berhasil meningkatkan pertumbuhan ekonomi.

Variabel dummy interaksi antara krisis global tahun 2008 dengan indeks diversifikasi ekspor bernilai negatif dengan nilai koefisien -9.208934. Variabel ini memiliki probabilitas sebesar 0.5460 yang berarti lebih besar dari taraf nyata 10 persen, maka terjadinya krisis global tahun 2008 yang diinteraksikan dengan nilai indeks diversifikasi ekspor tidak berpengaruh nyata terhadap pertumbuhan PDB per kapita negara anggota ASEAN. Pada kondisi tersebut, kebijakan spesialisasi ekspor mendominasi di ASEAN. Sehingga, fenomena krisis akan berpengaruh negatif terhadap pertumbuhan ekonomi di ASEAN. 


\section{KESIMPLAN DAN SARAN \\ Kesimpulan}

Indeks diversifikasi ekspor berpengaruh positif secara signifikan terhadap pertumbuhan ekonomi kawasan ASEAN. Semakin bertambahnya jenis produk dan negara tujuan ekspor atau dapat diistilahkan dengan diterapkannya kebijakan diversifikasi ekspor menjadi faktor penting yang dapat memperbesar kemampuan ekspor negara-negara di ASEAN. Begitu juga sebaliknya, kebijakan spesialisasi ekspor yang dominan diterapkan oleh negaranegara di ASEAN juga mampu meningkatkan pertumbuhan ekonomi, namun negara-negara yang menerapkan kebijakan diversifikasi ekspor akan mampu mempertahankan ekspor dalam kondisi stabil saat krisis melanda.

Mayoritas negara-negara di kawasan ASEAN tidak menerapkan kebijakan diversifikasi ekspor atau dengan kata lain sedang menerapkan kebijakan spesialisasi ekspor. Dua negara yang menerapkan kebijakan diversifikasi ekspor dalam kurun waktu 9 tahun terakhir berdasarkan penelitian adalah Vietnam dan Kamboja. Negara-negara tersebut telah mampu mempertahankan kondisi ekspornya dalam keadaan cenderung stabil saat krisis 2008 melanda.

\section{Saran}

Saran untuk penelitian selanjutnya adalah menambah deret waktu data agar keragaan data setiap variabel dapat lebih terlihat, serta menambah jumlah negara yang diteliti agar jangkauan penelitian semakin luas kebermanfaatannya. Misalnya membandingkan kebijakan diversifikasi ekspor antara negara anggota ASEAN dengan negara maju di Asia Timur seperti Jepang dan Korea Selatan. Selain itu, saran selanjutnya adalah mengagregasi indikator diversifikasi ekspor menjadi dua yaitu indikator untuk produk pertanian dan nonpertanian.

\section{DAFTAR PUSTAKA}

Aditya A, Acharyya R. 2013. Export Diversification, Composition and Economic Growth: Evidence from CrossCountry Analysis. The International Journal of Trade and Development. 22(7):959-992.

Amalia AA, Novianti T, Asmara A. 2018. Analisis Kinerja Perdagangan Indonesia ke Negara Potensial Benua Afrika. Jurnal Ekonomi dan Kebijakan Pembangunan, 7(1):43-59.

Bonaglia, Fukasaku. 2003. Export Diversification in Low Income Countries: An International Challenges After Doha. Working Paper No. 209. OECD Development Centre.

De Pinerez ASG, Ferrantino M. 1995. Export Diversivication and Structural Dynamics in the Growth Process: The Case of Chile. Journal of Development Economics. 52(1997):375-391.

Fitzsimons, Emla, Hogan, Neary. 1999. Explaining the Volume of North-South Trade in Ireland: A Gravity Model Approach. University College Dublin: The Economic and Social Review. 30(4).

Firdaus M. 2011. Aplikasi Ekometrika untuk Data Panel dan Time Series. Bogor (ID): IPB Press.

Hasanah, NN. 2015. Export Diversification in Indonesia Evaluating Its Effectiveness in Mantaining Economic Growth Stability Through Trade. [Tesis]. Bogor: Sekolah Pascasarjana, Institut Pertanian Bogor.

Herzer D, Nowak-Lehnmann DF. 2006. What Does Export Diversification Do for Growth? An Econometric Analysis. Applied Economics, vol. 38, no. 15, pp. 1825-1838.

Hesse, H. 2008. Export Diversification and Economic Growth. Working Paper No. 21, Commission on Growth and Development, World Bank.

Mankiw NG. 2007. Makroekonomi 6th ed. Jakarta (ID): Erlangga. 
Markusen JR, Melvin JR, Kaempfer WH, Maskus KE. 1995. International Trade:Theory and Evidence. Mcgraw Hill, United States of America.

[MoC] Ministry of Commerce Cambodia. 2014. Cambodia Export Diversification and Expansion Program Part1. Department of International Cooperation, Ministry of Commerce Cambodia.

Noureen, Mahmood. 2014. Explaining Trends and Factors Affecting Export Diversification in ASEAN and SAARC Regions: An Empirical Analysis. Working Paper No.4, School of Social Science and Humanities, National University of Science and Technology Pakistan.

Olaleye et al. 2013. Export Diversification and Economic Growth in Nigeria: An Empirical Test of Relationship Using a Granger Causality Test. Journal of Emerging Trends in Economics and Management Sciences, 5(1): 70-79.

Salvatore D. 1996. Ekonomi Internasional 5th ed. Jakarta: Erlangga.

Samen, S. 2010. A Primer on Export Diversification: Key Concepts, Theoretical Underpinnings, and Empirical Evidence. Growth and Crisis Unit, World Bank Institute.
Sari AR, Hakim DB, Anggraeni L. 2014. Analisis Pengaruh Non-Tariff Measures Ekspor Komoditi Crude Palm Oil (CPO) Indonesia ke Negara Tujuan Ekspor Utama. Jurnal Ekonomi dan Kebijakan Pembangunan, 3(2):111-135.

Sattar, Z. 2015. Strategy for Export Diversification 2015-2020: Breaking Into New Markets with New Product. Policy Research Institute of Bangladesh.

Siregar, Daryanto. 2005. Perkembangan dan Diversifikasi Ekspor Indonesia. Jurnal Manajemen dan Agribisnis IPB. 2(2):157165.

Siregar, Manning. 2001. Dynamics of Indonesian Agricultural and Manufacturing Exports: Differing Reactions to Exogenous Shocks. Mimeo, Fakultas Ekonomi dan Manajemen IPB.

Yusof ZA. 2011. Economic Diversification: The Case of Malaysia. Revenue Watch Institute.

Zulkarnaen I, Oktaviani R, Tambunan M, Yulius. 2012. Analisis Dampak Liberalisasi Perdagangan Kawasan Ekonomi Asia Terhadap Kinerja Ekonomi Makro ASEAN. Jurnal Ekonomi dan Kebijakan Pembangunan, 1(2):104-119. 